\title{
Budżet obywatelski województwa małopolskiego
}

Budżet obywatelski (partycypacyjny) uznaje się za narzędzie demokracji bezpośredniej. Jego istotą jest umożliwienie mieszkańcom decydowania w drodze głosowania o wydzielonej przez władze części budżetu jednostki samorządu terytorialnego. Instrument, który zyskuje coraz większą popularność w Europie oraz Ameryce, po raz pierwszy został wykorzystany w brazylijskim mieście Porto Alegre w 1989 r. ${ }^{1}$ Doświadczenia ponad 20 lat jego stosowania dowodzą, że okazał się on sukcesem. O ile w 1990 r. o kształcie budżetu decydowało jedynie 976 mieszkańców, o tyle w 2004 r. liczba ta wzrosła do ponad 50 tys. ${ }^{2}$ Ponadto w ciągu 10 lat od zainicjowania tego mechanizmu dochody miasta zwiększyły się dwukrotnie; z 5,5 do 18\% wzrósł udział podatków (stopniowo malała liczba uchylających się od jego płacenia); a dochody własne stanowiły $60 \%$ dochodów budżetowych (w przypadku większości jednostek samorządowych ok. $2 / 3$ dochodów stanowiły wpływy $\mathrm{z}$ budżetu centralnego) $)^{3}$. Podkreśla się również, iż w spotkaniach i głosowaniach brały udział osoby o najniższych dochodach, które zazwyczaj nie uczestniczą w życiu publicznym ${ }^{4}$. Budżet realizowano na trzech poziomach, tj. mieszkańcy (akcja informacyjna, otwarte spotkania władz z mieszkańcami, wybór delegatów reprezentujących osiedla), delegaci (szkolenia z zakresu tworzenia budżetu i zarządzania miastem, prace na forum delegatów, rozmowy z mieszkańcami, przedstawianie władzom postulatów i potrzeb obywateli), władze (analiza postulatów i potrzeb mieszkańców oraz zestawienie ich z dostępnymi środkami, spotkanie z mieszkańcami w celu omówienia kształtu budżetu i przyjętych do finansowania zadań) 5 .

${ }^{1}$ B. Michalak, A. Sokala, P. Uziębło, Leksykon prawa wyborczego i referendalnego oraz systemów politycznych, Warszawa 2013, s. 25.

2 M. Szaranowicz-Kusz, Budzet partycypacyjny w Polsce, „Infos” 2016, nr 1, s. 1.

${ }^{3}$ M. Burchard-Dziubińska, Budżet obywatelski jako partycypacyjna forma wspótrządzenia, „Studia i Prace Wydziału Nauk Ekonomicznych i Zarządzania” 2014, t. 2, nr 37, s. 200-201.

${ }^{4}$ C. Souza, Participatory budgeting in Brazilian cities: limits and possibilities in building democratic institutions, „Environment \& Urbanization” 2012, vol. 13, no. 1/04, s. 165.

${ }^{5}$ M. Serageldin i in., Assessment of Participatory Budgeting in Brazil, Harvard 2005, s. 21-22, https://www.mef.gob.pe/contenidos/pol_econ/documentos/Presupuesto_Participativo_Brasil_Efectos. 
W pierwszej dekadzie XXI w. formę tę implementowały liczne miejscowości europejskie, w tym wiele polskich jednostek samorządowych ${ }^{6}$. Zdaniem A. Ganuzo i G. Baiocchi, na przestrzeni lat model budżetu obywatelskiego wypracowany w Porto Alegre i naśladowany przez liczne jednostki samorządu terytorialnego ulegał modyfikacjom. $\mathrm{Z}$ instrumentu, którego istotą było wypracowanie priorytetów stanowiących podstawę przygotowania budżetu jednostki i opierającego się na spotkaniach informacyjnych z mieszkańcami oraz procesie deliberacji, stał się mechanizmem umożliwiającym mieszkańcom wskazanie zadań (najczęściej w drodze głosowania), które będą realizowane w ramach pewnej puli środków (zazwyczaj bardzo skromnych) wydzielonych z przygotowanego przez władze budżetu? To właśnie $\mathrm{z}$ takim mamy do czynienia $\mathrm{w}$ większości jednostek samorządowych w Polsce. Funkcjonujące w nich budżety obywatelskie są jednak różnorodne. Zróżnicowane są także efekty, jakie przynosi ich wykorzystanie ${ }^{8}$. Według Iwony Kowalskiej, wymierną korzyścią powinien być wzrost poziomu zadowolenia mieszkańców $\mathrm{z}$ usług publicznych oraz ich zaangażowania $\mathrm{w}$ życie publiczne ${ }^{9}$. Marta Szaranowcz-Kusz uważa z kolei, że dialog z obywatelami pozwala władzom na lepsze rozpoznanie potrzeb mieszkańców, a ci ostatni są lepiej poinformowani o planach i decyzjach podejmowanych przez rządzących ${ }^{10}$.

Celem niniejszego artykułu jest $\mathrm{z}$ jednej strony przybliżenie istoty klasycznego budżetu obywatelskiego i etapów jego realizacji (z Porto Alegre), a z drugiej - analiza funkcjonowania tej formy demokracji bezpośredniej w Polsce (na przykładzie budżetu województwa małopolskiego) oraz wskazanie przyczyn, dla których narzędzie to można także uznać za rodzaj konsultacji społecznych, a nie budżet obywatelski.

\section{Budżet obywatelski województwa małopolskiego}

Przeprowadzony w 2016 r. w Małopolsce budżet obywatelski był projektem pilotażowym. Władze województwa uznały, że będzie on dla mieszkańców okazją do wskazania i wyboru zadań, które ich zdaniem są najbardziej potrzebne.

pdf (dostęp 21.10.2016); B. de Sousa Santos, Participatory budgeting in Porto Alegre: Toward a redistributive democracy, „Politics \& Society” 1998, no. 4, s. 473-482.

${ }^{6}$ B. Michalak, A. Sokala, P. Uziębło, Leksykon...

7 E. Ganuza, G. Baiocchi, The power of ambiguity: How participatory budgeting travels the globe, ,Journal of Public Deliberation” 2012, vol. 8, no. 2, s. 4-6, http://www.publicdeliberation. net/jpd/vol8/iss2/art8/ (dostęp 21.10.2016).

${ }^{8}$ Y. Sintomer, C. Herzberg, A. Roecke, Budzet partycypacyjny w Europie-szanse i wyzwania, thum. M. Chustecka, http://ngo.chorzow.eu/_DOKUMENTY/budzet_partycypacyjny_w_europie. pdf (dostęp 21.10.2016).

9 I. Kowalska, Partycypacja spoleczna $w$ kształtowaniu budżetu jednostki samorzadu terytorialnego - budzet partycypacyjny, „Economic and Management” 2014, nr 4, s. 108-109.

${ }^{10}$ M. Szaranowicz-Kusz, Budżet partycypacyjny... 
Zgodnie z informacją przekazaną przez Zarząd Województwa Małopolskiego, przygotowanie regulaminu poprzedziły konsultacje ${ }^{11} \mathrm{z}$ organizacjami pozarządowymi oraz spotkania z mieszkańcami ${ }^{12}$.

Tryb i zasady przeprowadzenia budżetu określono w Regulaminie budżetu obywatelskiego województwa małopolskiego.Organem odpowiedzialnym za koordynację, działania informacyjne oraz promocyjne, a także edukacyjne dotyczące tej formy demokracji bezpośredniej był Zarząd Województwa Małopolskiego. Do jego zadań należało w szczególności: przybliżenie i wyjaśnienie mieszkańcom województwa idei i zasad budżetu obywatelskiego; zachęcanie do przygotowania i złożenia propozycji zadań oraz do głosowania; udostępnianie informacji o zgłoszonych przez mieszkańców propozycjach, wynikach głosowania, zadaniach wybranych do realizacji w ramach budżetu obywatelskiego oraz o efektach ich realizacji ${ }^{13}$

Możliwość składania wniosków, poparcia zadań oraz głosowania otrzymał każdy mieszkaniec Małopolski, który w dniu składania projektu miał ukończone 16 lat. W ramach budżetu obywatelskiego można było zgłosić propozycję, która pozytywnie wpływałaby na rozwój województwa. Zgłaszane zadania musiały być także zgodne z prawem, Strategią Rozwoju Województwa Małopolskiego na lata 2011-2020 oraz mieścić się w graniach kompetencji województwa małopolskiego ${ }^{14}$. Zgodnie z Regulaminem zadania miały mieć w szczególności charakter: prospołeczny, kulturalny, edukacyjny, sportowy, turystyczny lub ekologiczny. Te, które spełniały wymienione kryteria, mogły mieć zasięg powiatowy lub zasięg subregionalny.W pierwszym przypadku chodziło o zadanie służące mieszkańcom województwa i dotyczące danego powiatu albo miasta Kraków. Natomiast zadanie subregionalne także miało służyć mieszkańcom województwa, ale równocześnie dotyczyć co najmniej dwóch powiatów położonych w danym subregionie. W sumie wydzielono sześć następujących subregionów (rysunek 1):

1) subregion tarnowski - obejmujący miasto Tarnów i powiaty: brzeski, dąbrowski, tarnowski;

2) subregion sądecki - obejmujący miasto Nowy Sącz i powiaty: gorlicki, limanowski, nowosądecki;

${ }^{11}$ Zgodnie z Uchwałą nr XVI/223/15 sejmiku województwa małopolskiego z dnia 23 listopada 2015 r. w sprawie konsultacji wojewódzkich dotyczących projektu Budżetu Obywatelskiego Województwa Małopolskiego konsultacje miały być przeprowadzone na zasadach określonych w załączniku nr 1 do niniejszej uchwały. Zamiast niego do uchwały dołączony jest Regulamin budżetu obywatelskiego województwa małopolskiego, który jednak nie przewiduje takiej procedury, http://bip.malopolska.pl/umwm/Article/get/id,1139998.html (dostęp 27.12.2016).

${ }_{12}$ XVI Sesja Sejmiku Województwa Małopolskiego, https://bo.malopolska.pl/index.php/wydarzenia/14-xvisesja-sejmiku-wojewodztwa-malopolskiego (dostęp 25.11.2016).

${ }^{13} \S 8$ Regulaminu budżetu...

${ }^{14}$ Radni województwa przyjęli regulamin budżetu obywatelskiego, https://bo.malopolska.pl/index. php/wydarzenia/15-radni-wojewodztwa-przyjeli-regulamin-budzetuobywatelskiego (dostęp 25.11.2016). 
3) subregion podhalański - obejmujący powiaty: nowotarski, suski oraz tatrzański;

4) subregion Małopolska Zachodnia - obejmujący powiaty: chrzanowski, olkuski, oświęcimski, wadowicki;

5) Krakowski Obszar Metropolitalny (z wyłączeniem miasta Kraków) - obejmujący powiaty: bocheński, krakowski, miechowski, myślenicki, proszowicki, wielicki;

6) Miasto Kraków ${ }^{15}$.

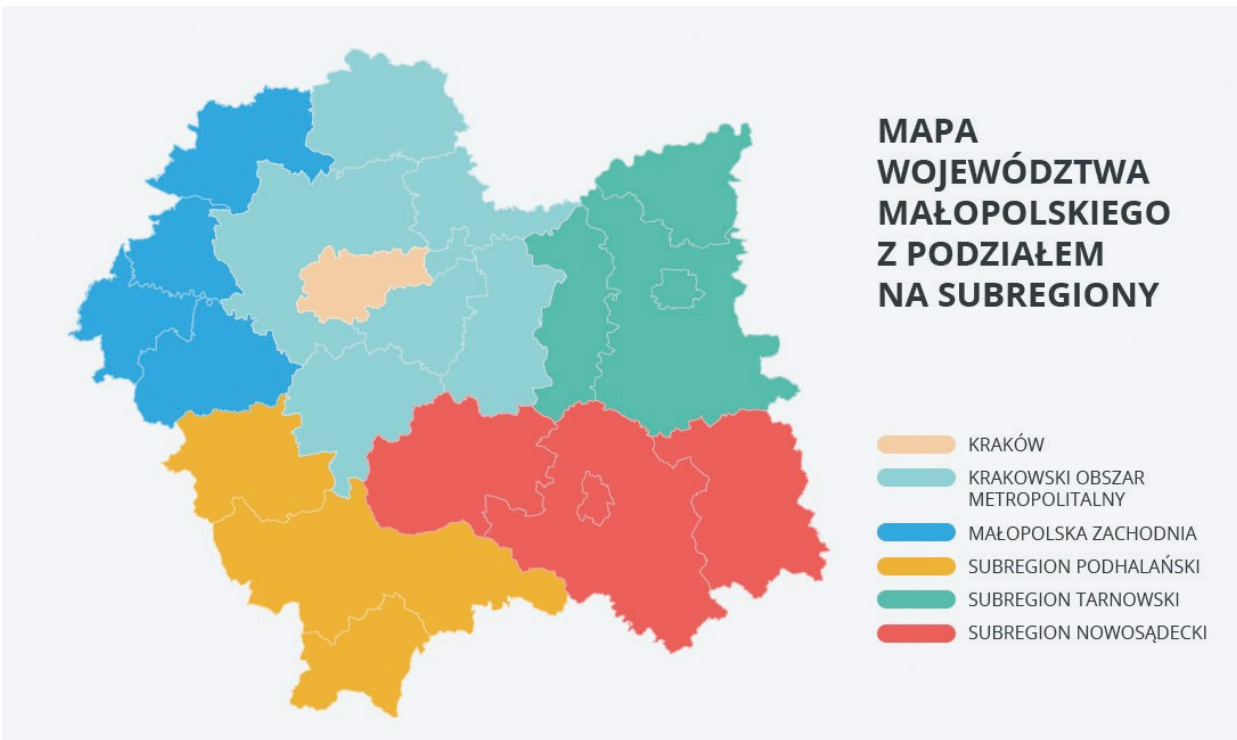

Rysunek 1 . Subregiony w województwie małopolskim

Źródło: https://bo.malopolska.pl/index.php/o-budzecie/5-subregiony-w-budzecie-obywatelskim (dostęp 26.11.2016).

Na wykonanie zadań przeznaczono łącznie $6 \mathrm{mln}$ zł - po $1 \mathrm{mln}$ zł na każdy subregion. Zastrzeżono także, iż szacunkowa wartość zgłaszanego przez mieszkańców zadania o zasięgu powiatowym nie może być niższa niż 50 tys. zł i wyższa niż 100 tys. zł, natomiast o zasięgu subregionalnym nie może być niższa niż 100 tys. zł ani wyższa niż 300 tys. zł. Istotne było także to, żeby koszty rocznego utrzymania zrealizowanego zadania nie przekroczyły $10 \%$ kwoty przeznaczonej na jego realizację ${ }^{16}$.

Zadania o zasięgu powiatowym mogły zgłaszać osoby mieszkające na terenie powiatu, którego dotyczyło zadanie, a o zasięgu subregionalnym - osoby zamieszkałe na terenie subregionu, którego dotyczyło zadanie. Zgłoszeń należało dokonywać

$15 \S 2$ Regulaminu budżetu...

16 Ibidem. 
na przygotowanym w tym celu formularzu. Można go było złożyć osobiście lub przesłać $^{17}$ do Urzędu Marszałkowskiego Województwa Małopolskiego, a także jednej z Agend Zamiejscowych w: Nowym Sączu, Oświęcimiu, Tarnowie. Do formularza wnioskodawca dołączał listę poparcia, wyrażoną podpisami: minimum 50 podpisów mieszkańców danego powiatu dla zadań o charakterze powiatowym i co najmniej 100 podpisów mieszkańców odpowiedniego subregionu, dla zadań o charakterze subregionalnym. Organizatorzy zastrzegli, iż nie będą rozpatrywane zgłoszenia dokonane po terminie oraz zawierające zadania, których koszt realizacji nie będzie zgodny z wytycznymi ${ }^{18}$.

Właściwe departamenty Urzędu Marszałkowskiego Województwa Małopolskiego dokonywały weryfikacji złożonych zadań pod kątem prawnym (ocena prawidłowości wypełnienia formularza zgłaszanego zadania i dołączonej do niego listy poparcia) oraz merytorycznym. W tym ostatnim przypadku brano pod uwagę przede wszystkim następujące kryteria:

- zgodność z obowiązującymi przepisami prawa (m.in. ze Strategia rozwoju województwa na lata 2011-2020),

- zgodność z kompetencjami i zadaniami województwa,

- wykonalność projektu,

- rzeczywisty koszt realizacji,

- możliwość zabezpieczenia w kolejnych budżetach województwa ewentualnych kosztów powstałych w wyniku realizacji zadania,

- możliwe korzyści wynikające dla Małopolski i jej mieszkańców, zgodne m.in. z dokumentami strategicznymi dotyczącymi województwa.

Ostateczną listę zadań dopuszczonych do głosowania oraz odrzuconych (wraz z uzasadnieniem) przyjmował Zarząd Województwa Małopolskiego. Listy ${ }^{19}$ były udostępniane na stronie internetowej województwa oraz wywieszono je w siedzibie Urzędu Marszałkowskiego Województwa Małopolskiego i siedzibach Agend Zamiejscowych ${ }^{20}$.

Decyzję o realizacji konkretnych zadań podejmowali w drodze głosowania mieszkańcy województwa, którzy najpóźniej w dniu głosowania ukończyli 16 lat. Władze umożliwiły oddanie głosu na trzy sposoby:

- tradycyjnie - poprzez wrzucenie karty do urny znajdującej się w Urzędzie Marszałkowskim Województwa Małopolskiego oraz Agendach Zamiejscowych,

- elektronicznie - wypełniając dostępny na stronie województwa małopolskiego formularz elektroniczny,

- korespondencyjnie - przesyłając kartę na adres Urzędu Marszałkowskiego Województwa Małopolskiego lub jednej z Agend Zamiejscowych.

${ }^{17}$ Decydująca była data wpływu do urzędu lub Agendy Zamiejscowej.

${ }^{18} \S 2$ Regulaminu budżetu...

${ }_{19} \mathrm{Z}$ chwilą udostępnienia list mieszkańcy mogli prowadzić akcję informacyjną dotyczącą zadań dopuszczonych do głosowania. § 4 Regulaminu budżetu...

${ }^{20} \S 3$ Regulaminu budżetu... 
Mieszkaniec mógł wybrać tylko jeden z wymienionych sposobów, ale miał możliwość zagłosowania na dwa zadania: jedno o zasięgu powiatowym, a drugie - subregionalnym. Jednym z warunków uznania głosu za ważny było zamieszkiwanie przez mieszkańca na terenie odpowiednio powiatu i subregionu, którego dotyczyły wybrane przez niego zadania ${ }^{21}$.

Liczenie głosów i ustalenie listy rankingowejej (na podstawie liczby oddanych głosów) należało do komisji powołanej przez Zarząd Wojewódzki. Do realizacji przechodziły zadania, na które w danym subregionie otrzymały kolejno największą liczbę ważnie oddanych głosów - aż do wyczerpania środków przeznaczonych dla subregionu, tj. $1 \mathrm{mln}$ zł. Jeżeli doszło do sytuacji, że dwa lub więcej zadań w określonym subregionie otrzymały tę samą liczbę głosów, o ich kolejności na liście zadecydować miało publiczne losowanie ${ }^{23}$. Z kolei, gdyby w wyniku głosowania dwa lub więcej wybranych zadań pozostawały ze sobą w sprzeczności lub wzajemnie się wykluczały, zrealizowane miało być zadanie, które zdobyło więcej głosów ${ }^{24}$. Interesującym rozwiązaniem był także zapis, zgodnie z którym w przypadku braku środków na realizację kolejnego zadania $\mathrm{z}$ listy, uwzględnione miało być pierwsze ze znajdujących się na liście zadań w danym subregionie, którego koszt realizacji nie przekroczy pozostałych środków ${ }^{25}$. W przypadku niewykorzystania puli środków przeznaczonych na sfinansowanie zadań w ramach budżetu obywatelskiego w danym subregionie Zarząd Województwa Małopolskiego mógł podjąć decyzję w sprawie przesunięcia tych środków do wykorzystania w innym subregionie. Warto zwrócić uwagę na jeszcze jedno rozwiązanie Regulaminu: jeśli w trakcie realizacji zadań z danego subregionu zostały poczynione oszczędności, zrealizowane mogą być kolejne zadania $\mathrm{z}$ listy zadań w danym subregionie, które zdobyły największą liczbę głosów spośród niezakwalifikowanych - aż do wyczerpania puli środków ${ }^{26}$.

Zrealizowany w 2016 r. w województwie małopolskim pilotażowy budżet obywatelski podzielono na cztery etapy:

1) składanie wniosków (do 6.05.2016 r.),

2) podanie wyników po weryfikacji wniosków (do 10.06.2016 r.),

3) głosowanie (od 18.06.2016 do 6.07.2016 r.),

4) podanie wyników głosowania (do 31.07 .2016 r.) ${ }^{27}$.

${ }^{21} \S 5$ Regulaminu budżetu...

${ }^{22} \mathrm{Na}$ liście rankingowej umieszczano zadania z kolejno największą liczbą ważnie oddanych w danym subregionie głosów.

${ }_{23}$ Tego typu sytuacja nie miała miejsca.

24 Jak wyżej.

${ }^{25}$ Odnotowano jeden przypadek w subregionie Krakowski Obszar Metropolitalny.

${ }^{26} \S 7$ Regulaminu budżetu...

${ }^{27}$ https://bo.malopolska.pl/index.php (dostęp 27.11.2016). 
W sumie zgłoszono 204 zadania $^{28}$, z czego pozytywną weryfikację przeszły 152 z nich, a decyzją mieszkańców zrealizowanych zostanie 46 (tabela 1). Głosy oddało 79708 osób. Najwięcej, bo 18 921, oddali mieszkańcy Krakowskiego Obszaru Metropolitalnego, a najmniej - 7003 mieszkańcy subregionu podhalańskiego. Najwięcej osób (45 338) oddało swój głos, wrzucając kartę do urny, 30742 osoby zdecydowały się na głosowanie internetowe, a jedynie 3626 skorzystało z metody korespondencyjnej. Biorąc pod uwagę przedziały wiekowe, najbardziej zainteresowane budżetem były osoby w wieku 26-35 lat (15 835 głosów) oraz w wieku 36-45 lat (15 613 głosów). Mieszkańcy województwa pomiędzy 16 a 25 rokiem życia oddali 11453 głosów, a 45-55-latkowie -11 441. Najliczniejszą grupą byli 36-latkowie, którzy oddali 1570 głosów. Zauważono także, że bardziej aktywne były kobiety - w głosowaniu uczestniczyło ich 45847 . Spośród zadań subregionalnych najwięcej głosów (4473) oddano na projekt Poprawa bezpieczeństwa na drogach wojewódzkich w gminach Biskupice, Czernichów, Kocmyrzów-Luborzyca, Liszki, Skawina, Zabierzów, Zielonki. Z kolei zwycięzcą w kategorii zadań powiatowych (3707 głosów) został projekt skierowany do osób niepełnosprawnych i ich rodzin Nic dwa razy się nie zdarzy ${ }^{29}$.

Tabela 1. Zadania w subregionach wybrane do realizacji przez mieszkańców województwa małopolskiego

\begin{tabular}{|c|l|c|}
\hline Lp. & \multicolumn{1}{|c|}{ KRAKOWSKI OBSZAR METROPOLITARNY } & $\begin{array}{c}\text { Liczba } \\
\text { głosów }\end{array}$ \\
\hline 1 & \multicolumn{1}{|c|}{2} & 3 \\
\hline 1 & $\begin{array}{l}\text { Poprawa bezpieczeństwa na drogach wojewódzkich w gminach Bisku- } \\
\text { pice, Czernichów, Kocmyrzów-Luborzyca, Liszki, Skawina, Zabierzów } \\
\text { i Zielonki }\end{array}$ & 4473 \\
\hline 2 & $\begin{array}{l}\text { Diagnoza i korekta wad postawy u uczniów klas IV i V szkół podstawo- } \\
\text { wych w gminach powiatu proszowickiego i gminie Igołomia-Wawrzeń- } \\
\text { czyce powiatu krakowskiego }\end{array}$ & 3214 \\
\hline 3 & Edukacja dla przyszłości & 2966 \\
\hline 4 & $\begin{array}{l}\text { Strój sportowy dla juniora na MINIMUNDIAL 2016 powiatu } \\
\text { krakowskiego }\end{array}$ & 1455 \\
\hline 5 & Przeprawa pieszo-rowerowa w Piekarach & 1447 \\
\hline 6 & Raj w Dolinie Racławki & \multicolumn{1}{|c|}{} \\
\hline
\end{tabular}

${ }^{28} 167$ zadań miało charakter powiatowy, a 37 subregionalny, co stanowi odpowiednio 81,9\% i 18,1\% zgłoszonych zadań. Raport z ewaluacji BO Małopolska, https://bo.malopolska.pl/index. $\mathrm{php/wydarzenia/61mieszkancy-zadowoleni-z-realizacji-bo-malopolska} \mathrm{(dostęp} \mathrm{27.12.2016).}$

${ }_{29}$ O budżecie. Wyniki I edycji budżetu obywatelskiego, https://bo.malopolska.pl/index.php/obudzecie (dostęp 27.11.2016). 
Tabela 1 (cd.)

\begin{tabular}{|c|c|c|}
\hline 1 & 2 & 3 \\
\hline 7 & $\begin{array}{l}\text { Wyposażenie Parafii oraz budynków gminnych w defibrylatory AED } \\
\text { w powiecie wielickim }\end{array}$ & 1276 \\
\hline \multicolumn{3}{|c|}{ MAŁOPOLSKA ZACHODNIA } \\
\hline 1 & $\begin{array}{l}\text { Nic dwa razy się nie zdarzy - zadanie skierowane do osób niepełno- } \\
\text { sprawnych i ich rodzin }\end{array}$ & 3707 \\
\hline 2 & $\begin{array}{l}\text { Wyposażenie Wojewódzkiego Szpitala Chorób Płuc i Rehabilitacji } \\
\text { w sprzęt rehabilitacyjny i uporządkowanie parku wokół Szpitala }\end{array}$ & 3529 \\
\hline 3 & Pociąg do Małopolski Zachodniej & 1614 \\
\hline 4 & $\begin{array}{l}\text { Wyposażenie Sali Doświadczenia Świata i Integracji Sensorycznej } \\
\text { do rehabilitacji osób z upośledzeniem umysłowym i ruchowym }\end{array}$ & 1470 \\
\hline 5 & $\begin{array}{l}\text { Poprawa jakości życia mieszkańców sołectwa Poręba Żegoty poprzez } \\
\text { przebudowę chodnika wzdłuż drogi wojewódzkiej nr } 780\end{array}$ & 1338 \\
\hline 6 & Centrum asystentury społecznej & 1102 \\
\hline $7 *$ & $\begin{array}{l}\text { Neurorehabilitacja - mózgowe porażenie dziecięce, udar mózgowy, } \\
\text { dyskopatia kręgosłupa, stwardnienie rozsiane, po urazach }\end{array}$ & 953 \\
\hline \multicolumn{3}{|c|}{ SUBREGION SĄDECKI } \\
\hline 1 & Pierwsza pomoc od podstawówki & 3002 \\
\hline 2 & Ryterska Akademia Muzyki i Tańca & 2047 \\
\hline 3 & Aktywni seniorzy & 1768 \\
\hline 4 & Plenerowe spotkania z nauką i kulturą & 1425 \\
\hline 5 & Szymbarska scena plenerowa & 1083 \\
\hline 6 & Ukwiecenie drogi wojewódzkiej w mieście Bobowa & 727 \\
\hline 7 & Nowy Sącz dla serca & 691 \\
\hline 8 & $\begin{array}{l}\text { Konserwacja wybranych zabytkowych kapliczek w pasie drogowym } \\
\text { dróg wojewódzkich na terenie Subregionu Sądeckiego }\end{array}$ & 637 \\
\hline \multicolumn{3}{|c|}{ SUBREGION TARNOWSKI } \\
\hline 1 & Z gwiazdami zaczytani & 3445 \\
\hline 2 & $\begin{array}{l}\text { Uniwersytet integracji międzypokoleniowej w Domu Ludowym } \\
\text { w Zbylitowskiej Górze }\end{array}$ & 2293 \\
\hline 3 & $\begin{array}{l}\text { Bezpieczny powiat dąbrowski z AED - każdy może uratować bezcenny } \\
\text { dar - ludzkie życie }\end{array}$ & 2154 \\
\hline
\end{tabular}




\begin{tabular}{|c|c|c|}
\hline 4 & $\begin{array}{l}\text { Wykonanie chodnika przy drodze wojewódzkiej nr } 977 \text { w miejscowości } \\
\text { Tarnowiec }\end{array}$ & 1823 \\
\hline 5 & $\begin{array}{l}\text { Półkolonie dla dzieci niepełnosprawnych połączone z rehabilitacją } \\
\text { ruchową i społeczną oraz edukacją dla rodziców }\end{array}$ & 1337 \\
\hline 6 & Tak wiele do odkrycia & 957 \\
\hline 7 & Galopem do sukcesu - lekcje jazdy konnej & 885 \\
\hline 8 & Małopolska Międzypokoleniowa Pracownia Medialna & 884 \\
\hline \multicolumn{3}{|c|}{ SUBREGION PODHALAŃSKI } \\
\hline 1 & $\begin{array}{l}\text {..Chodźcie na Turbacz... - nowe szlaki rowerowo-biegowe w Gorcach } \\
\text { (Obidowa, Nowy Targ, Waksmund, Ostrowsko, Łopuszna) }\end{array}$ & 2362 \\
\hline 2 & Pełnosprawni przez sport & 1302 \\
\hline 3 & Trasa rowerowa brzegiem Skawy i Skawicy - modernizacja & 938 \\
\hline 4 & $\begin{array}{l}\text { Zapobieganie nadwadze, otyłości oraz chorobom przewlekłym poprzez } \\
\text { edukację społeczeństwa w zakresie żywienia i aktywności fizycznej }\end{array}$ & 878 \\
\hline 5 & Mobilna scena plenerowa & 675 \\
\hline \multicolumn{3}{|c|}{ MIASTO KRAKÓW } \\
\hline 1 & Akademia Kobiecego Futbolu & 1276 \\
\hline 2 & $\begin{array}{l}\text { Kraków widziany oczami dziecka z zaburzeniami w komunikacji } \\
\text { językowej }\end{array}$ & 1069 \\
\hline 3 & $\begin{array}{l}\text { Siatkówka w Krakowie - ogólnorozwojowe zajęcia sportowe dla dzieci } \\
\text { i młodzieży z elementami siatkówki }\end{array}$ & 984 \\
\hline 4 & Przeprawa pieszo-rowerowa w Tyńcu & 964 \\
\hline 5 & Zakup aparatury medycznej do telemetrii & 590 \\
\hline 6 & Multikreatywne Warsztaty - świat inspiracji dla dzieci i rodziców & 555 \\
\hline 7 & Łąki kwietne dla Krakowa & 479 \\
\hline 8 & Stojaki na rowery (inspirowane pismem Stanisława Wyspiańskiego) & 301 \\
\hline 9 & ROWER CZY ROUTER? - czyli socjopodłączenie & 215 \\
\hline 10 & Zwiększenie kwalifikacji ratowników i dyspozytorów medycznych & 143 \\
\hline 11 & Krakowski Klub Seniora Kina Paradox & 137 \\
\hline
\end{tabular}

* Zadanie było ósme na liście, ale realizacja wcześniejszego spowodowałaby przekroczenie dostępnego dla subregionu budżetu, tj. $1 \mathrm{mln} \mathrm{zł}$.

Źródło: opracowanie własne na podstawie protokołu Dane o wynikach głosowania na poszczególne projekty zadań, https://bo.malopolska.pl/index.php/wyniki (dostęp 27.11.2016). 
Aktualnie (stan na 31.12.2016 r.) w trakcie realizacji jest 19 zadań, pozostałe mają zostać wykonane w roku 2017. Jeżeli władzom województwa małopolskiego uda się dotrzymać obietnicy i zrealizować zaplanowane zadania (albo przynajmniej większość z nich), to będzie to jeden z nielicznych przypadków w skali Polski, ponieważ w wielu jednostkach samorządu terytorialnego, w których przeprowadzono już kilka edycji budżetu obywatelskiego, nie zostały wykonane zadania nawet z projektów pilotażowych. W związku z tym realizacja prawie połowy wybranych przez mieszkańców zadań w ciągu pięciu miesięcy od zakończenia głosowania już jest sporym sukcesem. Warto zwrócić uwagę także na inne plusy małopolskiego budżetu obywatelskiego. Jednym z nich jest niewątpliwie dywersyfikacja sposobów głosowania (tradycyjne, korespondencyjne, elektroniczne), innym - znajdująca potwierdzenie w Regulaminie - obligatoryjność wykonania przez Zarząd Województwa Małopolskiego zadań wybranych przez mieszkańców. Na uwagę zasługuje także fakt, że zgłoszone i wskazane do realizacji przez Małopolan projekty są zróżnicowane i odbiegają od tendencji ogólnopolskiej - w większości przypadków mieszkańcy wybierają bowiem zadania związane $\mathrm{z}$ infrastrukturą drogową (budowa czy remont drogi lub chodników) oraz takie, których celem jest zaspokojenie interesów niewielkich grup, a nie społeczności lokalnej (dofinansowania działalności klubów sportowych, szkolnych kółek teatralnych, organizacji konkursów i wyjazdów zagranicznych). Dlatego nie jest przypadkiem, że w odniesieniu do budżetu wojewódzkiego dominują zadania z zakresu ochrony życia i zdrowia oraz kultury fizycznej i turystyki. Liczba zgłoszonych zadań: 167 o charakterze powiatowym, a jedynie 37 o subregionalnym potwierdza dotychczasowe badania wykazujące, że mieszkańcy jedynie w niewielkim stopniu czują się związani ze swoim województwem. W tym kontekście inicjatywa podjęta przez Urząd Marszałkowski Województwa Małopolskiego jest warta podkreślenia, ponieważ poza umożliwieniem Małopolanom wskazania zadań i obszarów, które ich zdaniem wymagają zainteresowania i wsparcia, jest to próba budowania więzi mieszkańców z regionem.

Nie do końca można jednak zgodzić się z opiniami władz, według których sukcesem jest frekwencja (79 708 osób) oraz kwota przeznaczona do dyspozycji Małopolan (6 mln zł). Po przeliczeniu stanowi to odpowiednio: 2,3\% mieszkańców województwa małopolskiego oraz $0,42 \%$ budżetu województwa. Jedną z przyczyn pierwszego wyniku może być mało urozmaicona i nie do końca trafiona kampania informacyjna. Ogłoszeń i reklam zachęcających do udziału w głosowaniu było niewiele, a spotkania władz z mieszkańcami ograniczono w zasadzie do 21 miast (stanowi to niespełna 12\% spośród jednostek samorządu terytorialnego województwa małopolskiego). Organizatorzy podkreślają także, iż 1/3 głosujących o budżecie obywatelskim dowiedziała się z mediów społecznościowych. Wynik jest faktycznie warty odnotowania, ale może równolegle należałoby korzystać z metod tradycyjnych (szczególne w gminach wiejskich sprawdza się informowanie mieszkańców z pomocą szkół czy parafii). Być może warto 
byłoby przemyśleć także kwestię dotyczącą zasadności podziału województwa na subregiony lub wybór zadania uzależnić od frekwencji obliczanej na podstawie liczby uprawnionych w danym subregionie do głosowania, a nie jedynie od liczby głosów oddanych na projekty. W związku z obecnymi regulacjami doszło do sytuacji, w której w Mieście Kraków przeszedł projekt, który uzyskał 137 głosów, a w Krakowskim Obszarze Metropolitarnym (z wyłączeniem Krakowa) nie będzie realizowane zadanie, które poparło 1248 osób.

\section{Podsumowanie}

W większości przypadków etapy realizacji budżetów obywatelskich przeprowadzanych w polskich jednostkach samorządu terytorialnego są podobne. Pierwsza faza polega na przygotowaniu przez władze regulaminu, następnie mieszkańcy zgłaszają projekty, które są weryfikowane przez rządzących lub wyznaczony do tego podmiot. Spośród projektów, które pozytywnie przejdą ten proces, mieszkańcy w drodze głosowania wybierają zadania przeznaczone do realizacji ${ }^{30}$. Przyjęcie takiego modelu ogranicza rolę mieszkańców w całym przedsięwzięciu. Pojawiają się nawet opinie, że budżet obywatelski umacnia pozycję władz, a nie przygotowuje mieszkańców do współzarządzania jednostką ${ }^{31}$. Innym problemem, na który często zwraca się uwagę, jest małe zainteresowanie obywateli zgłaszaniem projektów i wyborem zadań. Przykład Porto Alegre pokazuje jednak, że frekwencja nie jest kluczowym elementem tej formy demokracji bezpośredniej, szczególnie w pierwszych latach jej funkcjonowania. Istotny jest natomiast brak obligatoryjności wykonywania przez władze zadań wybranych przez mieszkańców oraz konkursowy charakter budżetów. Nie służy to bowiem deliberacji prowadzącej do wyłonienia najlepszych rozwiązań ${ }^{32}$.W związku z powyższymi spostrzeżeniami warto zastanowić się, czy funkcjonujący w większości polskich jednostek samorządu terytorialnego model jest budżetem obywatelskim. Jeżeli odniesiemy go do pierwowzoru (Porto Alegre), to odpowiedź będzie zdecydowanie negatywna. Natomiast, jeśli weźmiemy pod uwagę, że ewolucja instytucji politycznych i publicznych jest typowym zjawiskiem, to możemy uznać, że mamy do czynienia ze zmodyfikowanym modelem budżetu obywatelskiego (co postulują E. Ganuza i G. Baiocchi). W tym miejscu warto zwrócić uwagę na to, że model ten posiada cechy pozwalające uznać go za inną formę demokracji bezpośredniej - konsul-

${ }^{30}$ M. Szaranowicz- Kusz, Budżet partycypacyjny..., s. 1-2.

${ }^{31}$ W. Kębłowski, Budżet partycypacyjny. Ewaluacja, http://www.instytutobywatelski.pl/21598/ publikacje/raporty/raport-budzet-partycypacyjny-ewaluacja (dostęp 17.12.2016), s. 37.

${ }^{32}$ K. Łabędź, Partycypacja obywatelska na poziomie lokalnym - formy i ograniczenia, „Przegląd Politologiczny" 2015, nr 4, s. 99-100. 
tacje społeczne. Wprawdzie to mieszkańcy zgłaszają projekty zadań i wybierają, które spośród nich powinny zostać wykonane, ale ich weryfikacji dokonują władze. I nie robią tego jedynie w oparciu o kryteria formalne, ale także merytoryczne. Ponadto w większości przypadków rezultat głosowania nie jest wiążący dla władz i nie ma mechanizmu, który zmusiłby włodarzy do wykonania konkretnego zadania.

Część wskazanych w artykule minusów związanych z organizacją i przeprowadzeniem budżetu obywatelskiego dotyczy także tytułowej inicjatywy. Do słabych stron budżetu małopolskiego należą: niewielka frekwencja i wysokość przeznaczonych do rozdysponowania środków, uzależnienie realizacji zadania od liczby głosów w danym subregionie (i podział na subregiony), kampania informacyjna, spotkania organizowane jedynie w miastach, brak deliberacji i możliwości zaprezentowania przez pomysłodawców swoich projektów. W związku z tym, że była to edycja pilotażowa, to część z nich powinno zostać wyeliminowanych przy organizacji kolejnego budżetu. W odniesieniu do frekwencji warto zwrócić uwagę na to, iż województwo jest jednostką samorządową, z którą mieszkańcy utożsamiają się w najmniejszym stopniu, dlatego osiągnięta frekwencja nie powinna zniechęcać. Poza lepiej poprowadzoną przez organizatorów kampanią czynnikiem, który powinien w tym pomóc, będzie planowa realizacja wyłonionych w głosowaniu zadań. Optymizmem napawa także postawa samych mieszkańców, którzy wybierając projekty pokazali, że nie kierują się jedynie partykularnymi interesami. Niebagatelne znaczenie ma także fakt, że osobami, które czynnie zaangażowały się w kampanię, zachęcały mieszkańców do udziału w głosowaniu, prowadziły spotkania z mieszkańcami oraz na bieżąco informują o postępach w realizacji zadań, są członkowie Zarządu Województwa Małopolskiego. Po wyeliminowaniu wskazanych niedociągnięć istnieje duża szansa, że powyższe czynniki przełożą się na wzrost frekwencji i zainteresowania mieszkańców sprawami regionu.

\section{Bibliografia}

Burchard-Dziubińska M., Budżet obywatelski jako partycypacyjna forma wspótrządzenia, „Studia i Prace Wydziału Nauk Ekonomicznych i Zarządzania” 2014, t. 2, nr 37.

Ganuza E., Baiocchi G., The power of ambiguity: How participatory budgeting travels the globe, ,Journal of Public Deliberation” 2012, vol. 8, no. 2, http://www.publicdeliberation.net/jpd/vol8/iss2/art8/ (dostęp 21.10.2016).

Kębłowski W., Budżetpartycypacyjny. Ewaluacja, http://www.instytutobywatelski.pl/21598/ publikacje/raporty/raport-budzet-partycypacyjny-ewaluacja (dostęp 17.12.2016).

Kowalska I., Partycypacja społeczna w ksztattowaniu budżetu jednostki samorządu terytorialnego - budżet partycypacyjny, „Economisc and Management” 2014, nr 4.

Łabędź K., Partycypacja obywatelska na poziomie lokalnym - formy $i$ ograniczenia, „Przegląd Politologiczny” 2015, nr 4. 
Michalak B., Sokala A., Uziębło P., Leksykon prawa wyborczego i referendalnego oraz systemów politycznych, Warszawa 2013.

O budżecie. Wyniki I edycji budżetu obywatelskiego, https://bo.malopolska.pl/index.php/o-budzecie (dostęp 27.11.2016).

Radni województwa przyjęli regulamin budżetu obywatelskiego, https://bo.malopolska.pl/ index.php/wydarzenia/15-radni-wojewodztwa-przyjeli-regulamin-budzetuobywatelskiego (dostęp 25.11.2016).

Raport $z$ ewaluacji BO Małopolska, https://bo.malopolska.pl/index.php/wydarzenia/61mieszkancy-zadowoleni-z-realizacji-bo-malopolska (dostęp 27.12.2016).

Serageldin M. i in., Assessment of Participatory Budgeting in Brazil, Harvard 2005, https://www.mef.gob.pe/contenidos/pol econ/documentos/Presupuesto_Participativo_Brasil_Efectos.pdf (dostęp 21.10.2016).

Sintomer Y., Herzberg C., Roecke A., Budzet partycypacyjny w Europie - szanse i wyzwania, tłum. M. Chustecka, http://ngo.chorzow.eu/_DOKUMENTY/budzet_partycypacyjny_w_europie.pdf (dostęp 21.10.2016).

Sousa Santosde B., Participatory budgeting in Porto Alegre: Toward a redistributive democracy, „Politics \& Society” 1998, no. 4.

Souza C., Participatory budgeting in Brazilian cities: limits and possibilities in building democratic institutions,„Environment \& Urbanization” 2001, vol. 13, no. 1(04).

Szaranowicz-Kusz M., Budżet partycypacyjny w Polsce, „Infos” 2016, nr 1.

\section{Barbara Weglarz}

\section{Партиципаторный бюджет Малопольского Воеводства}

Гражданский бюджет это форма прямой демократии, которая в Польше становится все более популярной и используется во многих подразделениях местного самоуправления. Цель этой статьи будет с одной стороны приблизить сущность классического гражданского бюджета и этапов его реализации, а с другой стороны - проанализировать функционирование этой формы прямой демократии в Польше (в основном на примере гражданского бюджета малопольского воеводства) и указать причины, по которым этот инструмент можно рассматривать как своего рода социальную консультацию а не гражданский бюджет.

Ключевые слова: гражданский бюджет, прямая демократия, местное самоуправление, Польша. 
Barbara Weglarz

\section{Participatory budgeting of Lesser Poland Voivodeship}

A participatory budgeting is a form of direct democracy, which in Poland has been gaining more and more popularity and is used in many local government units. The purpose of this article is, on one hand, to present the issue of a classic participatory budgeting, on the other hand to analyse the functioning of this form of direct democracy in Poland (especially the participatory budgeting of Lesser Poland province) and to indicate the reasons for which this tool might be rather regarded as a kind of consultation than participatory budgeting.

Keywords: participatory budgeting, direct democracy, local government, Poland. 